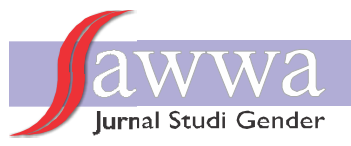

\title{
Problem Religiusitas dan Coping Spiritual pada Anak Berhadapan Hukum
}

\author{
Hasym Hasanah, \\ Ainun Fadlilah \\ Uiversitas Islam Negeri Walisongo \\ Semarang \\ email: hasyimhasanah_82@yahoo.co.id; \\ ainun3bersaudara@gmail.com
}

\begin{abstract}
This study aims to describe the problem of religiosity and spiritual coping of children in the law (Anak Berhadapan Hukum/ABH) of the boarding school Raden Sahid Mangunnan Lor Demak. The type of research is field research with the psycho-socio-religious approach. The main data were obtained from interviews with children in the face of law and religious counselors. Techniques of data collections use interview and documentation. Methods of data analysis using Miles and Huberman models include data reduction, data presentation, data verification, and conclusion drawing. The result of the research shows that the $\mathrm{ABH}$ at boarding school Raden Sahid Mangunan Lor Demak has a problem of religiosity. The religious problem of $\mathrm{ABH}$ consists of beliefs, ritual practices, appreciation, low knowledge, and religious experience. The efforts to handle the problem of religiosity of ABH in Islamic boarding school Raden Sahid Mangunan Lor Demak, one of them with the efforts of spiritual coping through habituation and exemplary. Habituation is directed to the ritual of coaching and spiritual practice. Exemplary strived through the role of peers, religious counselors, and tutor Islamic boarding school in implanting spiritual values for the ABH. Spiritual and exemplary practice proven to reduces the religious problem of $\mathrm{ABH}$ especially on aspects of belief, knowledge, and appreciation.
\end{abstract}

\section{Keywords: $\mathrm{ABH}$; religious; spiritual coping}

Abstrak: Penelitian ini bertujuan mendeskripsikan problem religiusitas dan coping spiritual anak berhadapan hukum $(\mathrm{ABH})$ di pondok pesantren Raden Sahid Mangunnan Lor Demak. Jenis penelitian adalah penelitian lapangan dengan pendekatan psiko sosio religius. Data utama diperoleh dari hasil wawancara dengan anak berhadapan hukum dan pembimbing agama. Teknik pengambilan data menggunakan wawancara dan dokumentasi. Metode analisis data menggunakan model Miles dan Huberman meliputi reduksi data, penyajian data, verifikasi data, dan penarikan simpulan. Hasil penelitian menunjukkan bahwa $\mathrm{ABH}$ di pondok pesantren Raden Sahid Mangunan Lor Demak mengalami problem religiusitas. Problem religius $\mathrm{ABH}$ terdiri dari keyakinan, praktik ritual, penghayatan, pengetahuan dan pengalaman keagamaan yang rendah. Upaya menangani problem religiusitas anak berhadapan hukum di pondok pesantren Raden Sahid Mangunan Lor Demak, salah satunya dengan upaya coping 
spiritual melalui pembiasaan dan keteladanan. Pembiasaan diarahkan pada ritunitas pembinaan dan latihan spiritual. Keteladanan diupayakan melalui peranan sebaya, pembimbing agama, dan pengasuh pondok pesantren dalam menanamkan nilai spiritual bagi ABH. Pembiasaan spiritual dan keteladanan terbukti mengurangi problem religious $\mathrm{ABH}$ khususnya pada aspek keyakinan, pengetahuan, dan penghayatan.

Kata Kunci: anakberhadapan hukum $(\mathrm{ABH})$; religiusitas; coping spiritual

\section{A. Pendahuluan}

Maraknya kasus kejahatan menjadikan semua pihak menjadi geram dan prihatin. Terlebih apabila kasus kejahatan tersebut dilakukan oleh anak. Gafoer, dkk., menyebutkan bahwa tahun 2008-2011 terdapat 29 kasus penganiayaan yang dilakukan oleh anak-anak. ${ }^{1}$ Putra menyebutkan bahwa di Palangkaraya pada tahun 2013 tercatat 3.335 anak menjadi narapidana, 3.282 anak laki-laki dan 73 anak perempuan. ${ }^{2}$ Komisi Nasional Perlindungan Anak (Komnas PA) seperti dikutip oleh Sholikhati menyebutkan bahwa tahun 2010 terjadi 2.413 kasus kriminal anak usia sekolah. Tahun 2011 terjadi peningkatan sebanyak 2.508 kasus. Trimester pertama tahun 2012 sebanyak 2.008 kasus kriminal dilakukan anak usia sekolah dan diperkirakan jumlah tersebut terus meningkat setiap tahunnya. ${ }^{3}$ Data tersebut mengindikasikan bahwa anak juga dapat menjadi pelaku kejahatan, dan memerlukan penanganan secara serius, mengingat anak merupakan generasi penerus harapan bangsa. Anak dengan kasus hukum biasa dikenal anak berhadapan hukum (ABH). ABH sebagaimana dijelaskan dalam Pasal 1 Nomor 3 tahun 1997 tentang Pengadilan Anak merupakan orang yang telah mencapai usia 8 sampai 18 tahun dan belum menikah. ${ }^{4} \mathrm{ABH}$ dalam

${ }^{1}$ Abdul Rahmat Gafoer, M. Syukri Akub, and Muhadar, "Anak Sebagai Pelaku Tindak Pidana Penganiayaan" (makalah, Fakultas Hukum Program Pascasarjana (S2) Universitas Hasanuddin Makassar, n.d.), 7-8.

${ }^{2}$ Redian Syah Putra and Yoskar Kadarisman, "Kriminalitas di Kalangan Remaja (Studi terhadap Remaja Pelaku Pencabulan di Lembaga Pemasyarakatan Anak Kelas II B Pekanbaru)," Jurnal Online Mahasiswa (JOM) Bidang Ilmu Sosial dan Ilmu Politik 3, no. 1 (2016): 1-14, https://jom.unri.ac.id/ index.php/JOMFSIP/article/view/9336.

${ }^{3}$ Yunisa Sholikhati et al., "Anak Berkonflik dengan Hukum (ABH), Tanggung Jawab Orang Tua Atau Negara?," in Seminar Psikologi dan Kemanusiaan (Malang: Psychology Forum UMM, 2015), http://mpsi.umm.ac.id/files/file/464-469 Yunisa S.pdf.

${ }^{4}$ R. Wiyono, Sistem Peradilan Pidana Anak di Indonesia (Jakarta: Sinar Grafika, 2016), 6. 
pemahaman psikologi perkembangan masuk dalam usia remaja. Usia remaja mengalami perubahan fisik yang sangat cepat dan mencapai puncaknya. Remaja mengalami ketidakseimbangan emosional dan ketidaksetabilan dalam banyak hal, mencari identitas dan hubungan sosial yang berubah. ${ }^{5}$ Hikmah menyebutkan bahwa remaja mengalami perkembangan kognitif. Perkembangan kognitif merupakan perubahan kemampuan mental seperti pemahaman, penghayatan, penalaran, pemikiran, dan kemampuan yang berkaitan dengan bahasa. ${ }^{6}$ Perkembangan kognitif remaja berpengaruh terhadap sikap seperti perilaku sosial, penerimaan nilai-nilai norma, dan agama.

Perkembangan kognitif masa remaja merupakan gerak peralihan cara berpikir konkret menuju cara berpikir yang proposional. Perkembangan kognitif memberi kemungkinan remaja meninggalkan agama anak-anak dan mulai memikirkan konsep serta bergerak menuju agama yang sifatnya personal. Pada masa tersebut, remaja mulai bersikap kritis terhadap ide-ide agama, dasar dan pokok agama, serta pengetahuan agama. Pengetahuan agama ditunjukkan dengan kepribadian yang sesuai dengan ajaran agama seperti sikap, mental, dan akhlak al-karimah. ${ }^{8}$ Ketidakstabilan remaja pada agama, dapat memengaruhi keyakinannya pada Tuhan, penghayatan dan perilaku keagamaan menjadi kuat atau lemah, bahkan mengalami keraguan yang ditandai adanya konflik dalam kehidupannya. Konflik agama pada remaja dapat berdampak pada sikap dan perilaku yang tidak sesuai dengan norma seperti kenakalan, perbuatan yang bersifat amoral, maupun anti-sosial. Perbuatan kriminal mencerminkan perilaku remaja yang tidak sesuai antara pemahaman agama, sikap, dan perilakunya. Hal tersebut menunjukkan religiusitas rendah pada remaja.

Aviyah menyebutkan bahwa sebanyak 100 orang siswa memiliki tingkat religiusitas rendah dan berakibat pada kenakalan remaja. ${ }^{9}$ Pandangan sama

${ }^{5}$ Elizabeth B. Hurlock, Perkembangan Anak (Jakarta: Erlangga, 2013), 38.

${ }^{6}$ Siti Hikmah, Psikologi Perkembangan: Tinjauan dalam Persepektif Islam (Semarang: Karya Abdi Jaya, 2015), 220-224.

7Sururin, Ilmu Jiwa Agama (Jakarta: Raja Grafindo Persada, 2004), 67.

8Zakiah Daradjat, Ilmu Jiwa Agama (Jakarta: Bulan Bintang, 1979), 107.

'Evi Aviyah and Muhammad Farid, "Religiusitas, Kontrol Diri dan Kenakalan Remaja," Persona: Jurnal Psikologi Indonesia 3, no. 2 (2014): 126-29, https://doi.org/10.30996/persona.v3i02.376. 
dikemukakan Aini bahwa remaja pemahaman keagamaan remaja sangat penting untuk mengurangi perilaku seks bebas, semakin tinggi pemahaman keagamaan remaja, maka semakin rendah perilaku seks bebas. ${ }^{10}$ Rahmawati menyebutkan bahwa pengguna internet yang memiliki religiusitas rendah, cenderung memiliki perilaku mengakses situs porno dalam waktu akses perminggu antara satu sampai delapan jam.11 Elga menyebutkan bahwa meningkatnya kasus kejahatan atau pelanggaran hukum pada remaja seperti pencurian sepeda motor, bukan hanya merupakan kenakalan remaja namun kejahatan anak, yang disebabkan transisi remaja tanpa penerimaan diri, penguatan perilaku, dan sistem pendukung sosial, melainkan juga karena persoalan keberagamaan remaja yang rendah..$^{12}$ Perilaku kejahatan yang dilakukan oleh ABH membuktikan rendahnya religiusitas anak. Problem rendahnya religious anak terlihat dari Tabel 1.

Data tersebut menunjukkan bahwa $\mathrm{ABH}$ memiliki problem religiusitas yang perlu mendapat penanganan secara komprehensip dan membutuhkan upaya solutif, dalam rangka menangani problem religiusitas anak khususnya ABH. Remaja yang memiliki religiusitas rendah cenderung tidak dapat menghindari perbuatan yang dilarang agama, sehingga melakukan perbuatan kriminal. Perbuatan kriminal remaja menjadi perhatian semua kalangan, sehingga perlu ditingkatkan pengawasan dalam perubahan sosial. ${ }^{13}$ Banyak lembaga yang memiliki interes tinggi dan berupaya menangani problem $\mathrm{ABH}$. $\mathrm{ABH}$ selain membutuhkan penanganan hukum, juga membutuhkan upaya pendampingan dan bimbingan, yang dimungkinkan dapat meredamkan emosi, sehingga perubahan tingkah laku $\mathrm{ABH}$ dapat mengurangi tingkat perbuatan kriminal. Salah satu usaha adalah melalui coping strategy.

\footnotetext{
${ }^{10}$ Hartin Suidah, "Hubungan Pemahaman Tingkat Agama (Religiusitas) dengan Perilaku Seks Bebas pada Remaja di SMAN 1 Bangsal Mojokerto," Jurnal Keperawatan \& Kebidanan 7, no. 2 (2015): 63-68.

"Diah Viska Rahmawati, M Noor Rochman Hadjam, dan Tina Afiatin, "Hubungan Antara Kecenderungan Perilaku Mengakses Situs Porno dan Religiusitas pada Remaja," Jurnal Psikologi 29 , no. 1(2002): 1-13, https://doi.org/10.22146/JPSI.7044.

"Elga Andina, "Kejahatan Sadis Oleh Remaja: Studi Kasus Begal Sepeda Motor Di Kota Depok," Aspirasi: Jurnal Masalah-Masalah Sosial 6, no. 2 (2015): 145-58, http://jurnal.dpr.go.id/index.php/ aspirasi/article/view/623.

${ }^{13}$ Sudarsono, Etika Islam tentang Kenakalan Remaja (Jakarta: Rineka Cipta, 2008), 6.
} 
Tabel 1.

Problem Religiusitas ABH Pondok Pesantren Mangunan Lor Demak

\begin{tabular}{|c|c|c|c|}
\hline No. & Dimensi & Problem Keberagaamaan & Jumlah \\
\hline 1 & Keyakinan & $\begin{array}{l}\text { Kurang yakin dan bertakwa kepada Allah, } \\
\text { beribadah karena ikut-ikutan. }\end{array}$ & $\begin{array}{l}\text { Tujuh anak (Sy, Un, } \\
\text { Wn, An, Ay, Wh, Ad) }\end{array}$ \\
\hline 2 & Praktik ritual & $\begin{array}{l}\text { Kurang disiplin beribadah, tidak } \\
\text { menjalankan puasa Ramadhan, malas } \\
\text { shalat berjamaah. }\end{array}$ & $\begin{array}{l}\text { Sembilan anak (Sb, } \\
\text { Un, Sy, Ar, Ad, As, Af, } \\
\text { Sj, Wn, Wh) }\end{array}$ \\
\hline 3 & Penghayatan & $\begin{array}{l}\text { Tidak mau tau dengan perbuatan yang } \\
\text { dilakukan, tidak dapat memaknai setiap } \\
\text { aturan dan ajaran agama. }\end{array}$ & $\begin{array}{l}\text { Enam anak (Un, An, } \\
\text { Ar, Wh, Ad, Sj) }\end{array}$ \\
\hline 4 & Pengetahuan & $\begin{array}{l}\text { Belum memahami nilai agama, rendahnya } \\
\text { pengetahuan tentang rukun iman dan } \\
\text { Islam, serta pengetahuan keislaman. }\end{array}$ & $\begin{array}{l}\text { Enam anak (Sy, Wn, } \\
\text { Ay, Ar, Wh, Ad) }\end{array}$ \\
\hline 5 & $\begin{array}{l}\text { Pengalaman } \\
\text { keagamaan }\end{array}$ & $\begin{array}{l}\text { Berperilaku amoral, melanggar aturan, } \\
\text { melakukan perbuatan yang dilarang } \\
\text { seperti mencuri, minum-minuman keras. }\end{array}$ & $\begin{array}{l}\text { Tujuh anak (Sb, Un, } \\
\text { Sy, Ar, Ad, As, Af) }\end{array}$ \\
\hline
\end{tabular}

Sumber: Hasil wawancara dengan ABH Pondok Pesantren Raden Sahid Mangunan Lor Demak

Coping strategy menggambarkan proses aktivitas kognitif, yang disertai dengan aktivitas perilaku. ${ }^{14}$ Coping strategy merupakan pilihan cara berupa respon perilaku, pikiran, serta sikap yang digunakan dalam memecahkan permasalahan, sehingga seseorang dapat beradaptasi dalam situasi yang menekan. ${ }^{15}$ Coping strategy menjadi upaya solutif atas problem religious yang dialami ABH.Salah satu lembaga yang memiliki perhatian dalam usaha coping spiritual para $\mathrm{ABH}$ adalah pondok pesantren Raden Sahid Mangunan Lor Demak.

Untuk mendapatkan gambaran tentang upaya coping spiritual bagi $\mathrm{ABH}$ yang diimplementasikan di pondok pesantren Raden Sahid, peneliti menggunakan jenis penelitian lapangan, dengan pendekatan psiko sosio spiritual. Data utama adalah hasil wawancara dengan $\mathrm{ABH}$ dan pembimbing agama. Selanjutnya penulis menganalisis data menggunakan model Miles dan Huberman.

${ }^{14}$ Andrew G. Billings and Rudolf H. Moos, "Coping, Stress, and Social Resources among Adults with Unipolar Depression," Journal of Personality and Social Psychology 46, no. 4 (1984): 877-91, https://doi.org/10.1037/0022-3514.46.4.877.

"Rahmad Purnama, "Penyelesaian Stress Melalui Coping Spiritual," Al-Adyan 12, no. 1 (2017): 7083, https://doi.org/10.24042/ADYAN.V12I1.1445. 


\section{B. Problem Religiusitas ABH di Pondok Pesantren Raden Sahid}

Pondok Pesantren Raden Sahid didirikan pada 15 Januari 2007 yang diasuh oleh Kiai Nur Chamid Karmany. Pondok pesantren Raden Sahid yang beralamat di dukuh Sampang 07/03 desa Mangunan Lor, Kebonangun Demak. Pondok pesantren tidak serta merta muncul begitu saja, namun berasal dari salah satu nama walisongo yaitu Sunan Kalijaga. Pondok Pesantren Raden Sahid berusaha menjadikan suatu lembaga dalam membantu anak-anak yang tidak mampu, memberi pendidikan tanpa biaya. Pondok pesantren Raden Sahid menangani fakir, miskin, yatim, anak jalanan, anak terlantar, dan anak berhadapan hukum. Pondok pesantren Raden Sahid bertujuan merubah perilaku anak menjadi berakhlak mulia. Menerapkan ajaran-ajaran agama Islam yang telah diberi pemahaman oleh Rasulullah. Pondok pesantren Raden Sahid menjadi Lembaga Kesejahteraan Sosial Anak (LKSA) unggulan di wilayah Jawa Tengah, mengantarkan anak asuh berahlak mulia, berprestasi, memiliki kecakapan hidup (life skill), berwawasan global, dan berkarakter kebangsaan Indonesia. Pondok pesantren Raden Sahid menjadi lembaga pendidikan agama dan banyak mengkaji kitab-kitab kuning sebagai pedoman dan khas pesantren salafiyah. Pondok Pesantren sebagai sentral pelaksanaan pendidikan dasar sembilan tahun formal dan non formal di Indonesia, dengan meningkatkan mutu pendidikan pesantren dengan sistem terpadu, dalam proses diberi pemahaman mengajar pengembangan pendidikan agama melalui bidang seni, olahraga, dan keterampilan santri.16

Pondok Pesantren Raden Sahid memiliki 15 ABH. ABH di Pondok Pesantren Raden Sahid memiliki keunikan dibandingkan dengan santri lain. ABH masuk Pondok Pesantren disebabkan oleh kasus kriminal yang dibawa langsung oleh pihak kepolisian. Kasus kriminal ABH berupa pencurian, minumminuman, dan seksual. Kasus pencurian terdiri dari delapan orang, kasusu minum-minuman sebanyak empat orang, dan kasus seksualitas sebanyak tiga orang. ${ }^{17}$ Kasus $\mathrm{ABH}$ berupa pencurian pada umumnya terjadi karena keadaan ekonomi. ${ }^{18}$ Pada $\mathrm{ABH}$ dengan kasus minum-minuman dan seksualitas pada

\footnotetext{
${ }^{16}$ Data profil Pondok Pesantren Raden Sahid Mangunan Lor Demak

${ }^{17}$ Buku Data Kasus dan Penanganan Pembimbing di Pondok Pesantren Raden Sahid

18Wawancara dengan ustaz Anas, tanggal 23 September 2017.
} 
umumnya disebabkan karena keadaan yang dialaminya, moralitas yang rendah, yang berakibat $\mathrm{ABH}$ bertindak tidak sesuai dengan aturan. $\mathrm{ABH}$ berperilaku tidak beraturan menunjukan kurangnya pemahaman nilai-nilai moral yang berlaku.

Darajat menyebutkan bahwa nilai moral yang tidak didasarkan kepada agama terus berubah sesuai dengan keadaan, waktu, dan tempat. ${ }^{19}$ Nilai yang berubah-ubah menimbulkan kegoncangan, menyebabkan orang hidup tanpa pegangan yang pasti, sebaliknya nilai tetap dan tidak berubah adalah nilai-nilai agama, karena nilai agama bersifat pasti dan berlaku sepanjang zaman. ABH yang kuat keyakinan beragamanya mampu mempertahankan nilai agama yang pasti dalam kehidupannya sehari-hari dan tidak terpengaruh oleh arus kemerosotan moral, sehingga pada perilaku ABH menunjukkan sikap yang sesuai dengan nilai-nilai agama. Namun, realitas menunjukkan $\mathrm{ABH}$ mengalami problem moralitas dan keagamaan, sehingga menimbulkan perilaku kriminal.

Data problem religiusitas ABH di Pondok Pesantren Raden Sahid terdiri dari lima bentuk yaitu problem keyakinan, pengetahuan agama, ritual agama, penghayatan, dan pengamalan. Problem keyakinan berupa kurangnya kepercayaan (beliefs) ABH, rendahnya pengharapan-pengharapan dimana orang beragama berpegang teguh pada pandangan agama tertentu dan mengakui kebenaran doktrin-doktrin tersebut serta mentaatinya. Dimensi keyakinan menyangkut keyakinan tentang adanya Allah, Malaikat, Rosul/Nabi, kitab Allah, surga, neraka, qadha dan qadar. Problem keyakinan terjadi pada 7 (tujuh) ABH yaitu Sy, Un, Wn, An, Ay, Wh, dan Ad. Problem keyakinan ABH berupa rendahnya kepercayaan kepada Tuhan, kurang patuh kepada Allah. Ketidakmampuan ABH meyakini kekuasaan Tuhan diakibatkan karena perasaan kesal, marah, dan sedih, karena tidak mampu memenuhi kebutuhan hidupnya. Hilangnya kepercayaan kepada Tuhan, karena hidup dalam kondisi serba kekurangan. Himpitan ekonomi yang dialami ABH dan keluarganya menjadikan hilangnya keyakinan pada kekuatan Tuhan. Problem keyakinan juga ditunjukkan dari ketidakmampuan $\mathrm{ABH}$ menerima kenyataan hidup, cobaan, dan ujian. $\mathrm{ABH}$ cenderung menyalahkan Tuhan, dan enggan mensyukuri pemberian atau rezeki yang Allah berikan.

${ }^{19}$ Daradjat, Ilmu Jiwa Agama, 127. 
Problem religiusitas kedua ditunjukkan dari rendahnya pengetahuan agama $\mathrm{ABH}$. Dimensi pengetahuan mengacu kepada harapan bahwa orangorang yang beragama memiliki sejumlah pengetahuan dan pemahaman mengenai dasar-dasar keyakinan, ritus, kitab suci, dan tradisi-tradisi yang berlaku di dalam ajaran agamanya. Di dalam keberislaman isi pengetahuan meliputi paham membaca dan menulis, serta mengerti isi al-Qur'an, pokok-pokok ajaran yang harus diimani dan dilaksanakan (menyangkut rukun Islam dan iman), hukum Islam, sejarah Islam. Problem pengetahuan agama diwujudkan dari ketidakmampuan ABH memahami ajaran Islam dengan baik. Terdapat 6 (enam) ABH yang mengalami problem pengetahuan agama yaitu $\mathrm{Sy}, \mathrm{Wn}, \mathrm{Ay}$, Ar, Wh, Ad. Kurangnya pemahaman, ketidaktahuan mengenai perilakuperilaku yang tidak sesuai dengan nilai-nilai agama, dan pada praktek ibadah santri ABH tidak sesuai dengan ketentuan ajaran agama. Tidak jarang ABH belum memahami rukun iman, rukun Islam, bahkan membaca al-Qur'an. Menurut pembimbing agama pondok pesantren Raden Sahid, hampir sebagian besar $\mathrm{ABH}$ memiliki latar belakang pendidikan rendah, sehingga berakibat pada tingkat pemahaman keagamaannya. Maka memberikan pemahaman menjadi hal terpenting yang diilakukan oleh pondok pesantren Raden Sahid.

Problem pengamalan atau ritual agama. Memperhatikan fakta bahwa semua agama mengandung pengharapan-pengharapan tertentu, meski tidak tepat jika dikatakan bahwa seseorang yang beragama dengan baik pada suatu waktu mencapai pengetahuan subjektif dan langsung mengenai kenyataan terakhir (kenyataan terakhir bahwa mencapai suatu kontak dengan kekuatan supranatural). Ritual agama merupakan bagian keagamaan yang bersifat afektif, yaitu keterlibatan emosional dan sentimental terhadap pelaksanaan ajaran agamanya. Perasaan keagamaan melilputi empat tingkatan, yaitu: konfirmatif (merasakan kehadiran Tuhan terhadap pengalaman); responsif (merasa bahwa Tuhan menjawab kehendak atau keluhannya); eskatik (merasakan hubungan yang akrab dan penuh cinta antara Tuhan, manusia dan alam semesta) dan partisiperty (merasa menjadi bagian, kawan, kekasih atau wali dan mengerti pengalaman ilahiyah). Dimensi ritual berkaitan dengan pengalaman keagamaan, perasaan, persepsi dan sensasi-sensasi yang dialami seseorang, didefinisikan oleh suatu kelompok keagamaan (suatu masyarakat) yang melihat komunikasi walaupun kecil, dalam suatu esensi ketuhanan yaitu 
dengan Tuhan, kenyataan terakhir dan otoritas transendental. Ritual Islam mencakup perasaan dekat dengan Allah, dicintai Allah, doa-doa sering dikabulkan, perasaan terteram dan bahagia karena menuhankan Allah, bertawakal dan bersyukur kepada Allah dan lain sebagainya. Problem ritual dialami oleh $\mathrm{ABH}$ sebanyak 7 (tujuh) orang yaitu Sb, Un, Sy, Ar Ad, As, Af. ABH cenderung berperilaku amoral, suka melanggar aturan, melakukan perbuatan yang telah dilarang agama, dan berperilaku menyimpang. Menurut $\mathrm{ABH}$ Ad dan As kurangnya pengetahuan menjadi kendala tidak bisa mengikuti kegiatan keagamaan. ${ }^{20} \mathrm{ABH}$ kurang memahami ritual ajaran agama Islam, seperti salat, membaca al-Qur'an, diba'an (membaca selawatan), ABH hanya sekedar mengikuti kegiatan. Dilihat dari implementasi ritual, $\mathrm{ABH}$ menunjukkan perilaku amoral, suka melanggar aturan, dan berperilaku melanggar nilai-nilai agama seperti mengambil barang orang lain. Kurangnya kesadaran ABH pada nilainilai agama dan nilai-nilai moral, sehingga $\mathrm{ABH}$ bertindak sesuka hatinya tanpa menyadari akibat dari perbuatannya tersebut.21 Perilaku amoral diakibatkan kurangnya penanaman nilai-nilai moral pada masa kecilnya. Akibatnya masa remaja $A B H$ tidak dapat mengontrol sikap dan perilakunya di lingkungan sekitar. $\mathrm{ABH}$ di Pondok Pesantren selalu mengikuti kegiatan yang ada di Pondok, walaupun terlihat jelas bahwa ABH mengikuti karena takut dimarah atau dihukum oleh pengasuh. Setiap kegiatan agama seperti salat, membaca alQur'an, shalawatan dan kegiatan lainnya, ABH tidak dapat mengikuti dengan baik, terbatasnya pengetahuan agama dalam beribadah kepada Allah membuat $\mathrm{ABH}$ sulit mengikuti kegiatan di Pondok. ${ }^{22}$ Problem lain dilihat dari cara melaksanakan ibadah dan ajaran-Nya sekedar mengikuti suasana lingkungan, kurang memahami setiap perbuatan bernilai di hadapan Allah, perbuatan baik bernilai pahala dan perbuatan yang melanggar ajaran agama bernilai dosa. Problem ritual agama terjadi pada 9 (sembilan) ABH: Sy, Sb, Un, Wn, An, Ar, Wh, $\mathrm{Ad}, \mathrm{Sj}$. Perilaku ABH ditandai dengan kurangnya disiplin dalam beribadah, seperti sering meninggalkan salat, malas mengikuti salat berjamaah, tidak menjalankan puasa, dan tidak membaca al-Qur'an.

\footnotetext{
20Wawancara dengan ABH Ad dan ABH As tanggal 8 Oktober 2017.

${ }^{21}$ Wawancara dengan Ustaz Anas, tanggal 5 Oktober 2017.

22Wawancara dengan Ustaz Ansori, tanggal 5 Oktober 2017.
} 
Problem penghayatan terjadi pada 6 (enam) ABH: Un, An, Sy, Ad, Im, Sm, ditunjukkan dengan sikap yang tidak menyadari bahwa setiap perbuatan pasti akan ada timbal baliknya dan tidak dapat memaknai ajaran agamanya dengan baik. Problem penghayatan berkaitan dengan perasaan seseorang pada saat mendekatan diri kepada Allah merasakan ketenangan, dan ketentraman jiwa. Rendahnya penghayatan ditunjukkan dari ketidakmampuan $\mathrm{ABH}$ dalam memaknai perbuatan yang dialaminya, memahami dan mengerti perilaku. Ketidaksadaran menjadikan perilaku tidak terkontrol, cenderung mudah tersulut emosi dan selanjutnya melakukan perbuatan yang bertentangan dengan ajaran agama, maupun nilai-nilai yang berlaku di dalam masyarakat.

Problem pengalaman berkaitan dengan bagaimana seseorang atau individu mengidentifikasi akibat-akibat dari keyakinan keagamaan, praktik, pengalaman-pengalaman dan pengetahuan seseorang dari hari kehari sehingga dapat dimotivasi oleh ajaran agamanya. Perilaku mengarah dalam hal perilaku duniawi, yakni bagaimana individu berelasi dengan dunianya. Aspek pengalaman Islam meliputi perilaku suka menolong, bekerjasama, berderma, menyejahterakan dan menumbuh kembangkan orang lain, menegakkan kebenaran dan keadilan, berlaku jujur, suka memaafkan, menjaga lingkungan hidup, menjaga amanat, mematuhi norma-norma Islam, tidak berjudi, mabuk-mabukan, mencaci, selalu berjuang untuk hidup sukses dan lain sebagainya. Problem pengalaman $\mathrm{ABH}$ berkaitan dengan perilaku suka mencuri, minum-minuman keras, dan terlibat perilaku seksual. Semua ABH yang ada di pondok pesantren Raden Sahid memiliki problem pengalaman.

Berdasarkan realitas tersebut, dapat disimpulkan bahwa para $\mathrm{ABH}$ memiliki problem religiusitas yang perlu penanganan sesuai dengan tingkat masalah yang dihadapinya. Hal ini dittujukan agar problem yang dihadapi, memiliki penanganan yang tepat, sehingga $\mathrm{ABH}$ memiliki perubahan orientasi keagamaan yang lebih baik, dan selanjutnya tidak mengulangi kesalahan atau kejahatan yang telah dilakukan.

\section{Coping Spiritual}

Manusia tidak lepas dari berbagai problem kehidupan. Jika masalah yang dihadapi dipandang negatif, menghasilkan respon prilaku negatif. Sebaliknya, jika masalah yang dihadapi dipandang positif, maka respon prilaku yang 
ditampilkan dalam bentuk penyesuaian diri yang sehat dan memiliki cara-cara mengatasi masalah secara konstruktif. Pemilihan cara mengatasi masalah disebut proses coping. ${ }^{23}$ Coping dipandang sebagai faktor yang menentukan kemampuan manusia melakukan penyesuaian terhadap situasi yang menekan (stressful life events). Coping menggambarkan proses aktivitas kognitif. Proses kognitif tersebut disertai dengan aktivitas perilaku. Coping juga berarti pilihan cara berupa respon perilaku, pikiran, serta sikap dalam memecahkan permasalahan, agar dapat beradaptasi dalam situasi menekan. Perilaku coping dapat memprediksikan berkuranngnya ketegangan (affect reduction), usaha menghibur diri. Perilaku tersebut selanjutnya dapat membantu menemukan pencarian tantangan dalam aktivitas baru, menyibukkan diri dalam pekerjaan, dan melaksanakan aktivitas baru. Menghibur diri merupkan usaha untuk menyenangkan dan membahagiakan diri sendiri.

Upaya coping secara umum juga diajarkan agama Islam. Al-Qur'an memberikan landasan an peddoman bagi pemeluknya untuk menemukan berbagai usaha menyelesaikan masalahnya dengan baik melalui bantuan orang lain, pemberian dukungan ataupun dengan pemahaman dan penanaman nilai-nilai keagamaan atau istilah lainnya dikenal dengan coping spiritual. Coping spiritual yang diajarkan Islam dilakukan dengan melalui do'a, praktik ritual agama seperti shalat, puasa, wisata religi, pemberian bimbingan dan pendampingan sehingga membantu menangani masalah. Coping spiritual dapat dilakukan melalui beberapa tahapan yaitu pemikiran positif, beraktivitas sebaik-baiknya, doa dan tawakal. Rammohan,dkk., menyebutkan bahwa terdapat tiga bentuk coping spiritual yaitu positive thinkink, positive acting, dan positive hoping.

Positive thingking merupakan usaha untuk selalu menghadirkan pikiran positif dalam menghadapi persoalan. Usaha yang dapat dilakukan untuk membuktikan seseorang memiliki pikiran positif adalah dengan mengarahkan kerja otak untuk selalu dapat menilai secara positif setiap hal yang terjadi pada dirinya. Penerimaan diri, menjadi tahap pertama dalam melakukan coping. Penerimaan diri membantu seseorang dalam menemukan pemikiran yang jernih, menemukan jalan keluar terbaik untuk setiap permasalahan, dan me-

${ }^{23}$ R. S. Lazarus, "Coping Theory and Research: Past, Present, and Future.," Psychosomatic Medicine 55, no. 3 (1993): 234-47, https://doi.org/10.1097/00006842-199305000-00002. 
nyiapkan usaha untuk menanganinya. Kedua adalah kesadaran. Kesadaran menjadi aspek kepribadian yang paling penting sehingga memungkinkan orang memunculkan pemahaman, pengertian, dan sadar tentang apa yang telah dilakukan. Kesadaran juga berarti kondisi mengerti dan paham dengan diri sendiri. Mengerti dan paham dengan diri sendiri penting untuk melakukan introspeksi diri atau evaluasi diri. Menemukan faktor dan penyebab dari kondisi yang dialami dan berpotensi terhadap masalah.

Positive acting merupakan usaha coping yang dilaakukan dengan aksi atau perilaku nyata. Mengerjakan amalan-amalan baik, dan ada usaha dalam menyelesaikan masalah yang dihadapinya secara mandiri. Perilaku positif didalam ajaran Islam diwujudkan dalam pembentukan karakter muslim melalui akhlak al karimah. Pembentukan karakter yang baik atau berakhlak dilakukan dengan pembiasaan perilaku baik dalam setia aktivitas. Pembiasaan merupakan salah satu bentuk menciptakan lingkungan dan iklim kondusif bagi diri sendiri. Dengan lingkungan dan iklim yang kondusif, menjadikan pikiran menjadi tenang, aman, sehingga mendorong orang berperilaku sebaik-baiknya dan berguna untuk orang lain.

Positive hoping merupakan usaha menangani masalah dengan mencari bantuan atau pertolongan kepada orang lain. Dalam hal ini berkaitan dengan adanya dukungan dan arahan dari orang yang berada di sekitar masyarakat yang nantinya berperan sebagai motivator, mediator, atau fasilitator. Bantuan positif juga dapat diupayaakan dengan usaha maksimal dari individu tersebut. Setiap orang yang berda dalam situasi masalah, harus membantu dirinya sendiri, dengan usaha sekuat tenaga, semangat, etos kerja, dan ikhtiar semaksimal mungkin. Islam menganjurkan setiap umatnya untuk melakukan ihtiar dengan sebaik-baiknya, agar setiap masalah yang dihadapi dapat secepatnya tertangani. Ihtiar juga berhubungan dengan harapan, sehingga setiap orang yang berusaha sekuat tenaga, cenderung memiliki pengharapan yang tinggi pula. Hal ini sesuai dengan teori motivasi yang dikemukakan oleh Herberg"s dalam Eccles dan Shia yang menyebutkan bahwa agar data terhindar dari kegagalan orang harus memiliki pengharapan untuk sukses..24 Berdasarkan

\footnotetext{
${ }^{24}$ Allan Wigfield and Jacquelynne S. Eccles, "Expectancy-Value Theory of Achievement Motivation," Contemporary Educational Psychology 25, no. 1 (January 1, 2000): 68-81, https://doi.org/ 10.1006/CEPS.1999.1015; Regina M. Shia, “Assessing Academic Intrinsic Motivation: A Look at Student
} 
pemahaman tersebut maka, usaha coping juga dapat diwujudkan degan usaha dan keteladanan yang baik.

\section{Problem Religiusitas dan Coping Spiritual pada Anak Berhadapan Hukum}

Problem relgiusitas $\mathrm{ABH}$ yang meliputi problem keyakinan, ritual, penghayatan, pemahaman dan pengaalaman merupakan problem yang umum dialami oleh anak. Hal ini sesuai dengan teori pertumbuhan jiwa pada anak dan remaja, bahwa masa anak dan remaja adalah masa pencarian identitas agama. Hurlock dan Thoules menyebutkan bahwa masa anak merupakan tahap pencarian jati diri dan penemuan identitas keagamaan. Karena masa anak dan remaja perkembangan kognitif sedang mengalami pertumbuhan dan perkembangan optimal. ${ }^{25}$ Problem keyakinan yang ditunjukkan dari ketidak mampuan $\mathrm{ABH}$ menghadirkan semangat ketuhanan di dalam dirinya mengakibatkan $\mathrm{ABH}$ tidak mempedulikan perilaku yang dilakukan. Kurangnya kepercayaan (beliefs) $\mathrm{ABH}$, rendahnya pengharapan-pengharapan dimana orang beragama berpegang teguh pada pandangan agama tertentu dan mengakui kebenaran doktrin-doktrin tersebut serta mentaatinya. Dimensi keyakinan menyangkut keyakinan tentang adanya Allah, Malaikat, Rasul/Nabi, kitab Allah, surga, neraka, qadha dan qadar. Keyakinan dan kepercayaan yang rendah berbanding lurus dengan perilaku yang dilakukan. Hasil penelitian Hasanah menyebutkan bahwa seorang yang mengalami problem keyakinan cenderung sulit menyadari hakikat penciptaannya, suka menyalahkan Tuhan, dan menganggap Tuhan tidak adil terhadap dirinya. ${ }^{26}$

Begitu pula dengan problem pengetahuan, pengalaman, dan ritual $\mathrm{ABH}$, tidak hanya menjadi persoalan yang biasa, namun $\mathrm{ABH}$ membutuhkan pe-

Goals and Personal Strategy" (Thesis, Wheeling Jesuit University, n.d.), 2-3, http://www.cetedu/ pdf/motivation.pdf.

${ }^{2}$ Elizabeth B. Hurlock, Psikologi Perkembangan: Suatu Pendekatan Sepanjang Rentang Kehidupan, ed. Ridwan Max Sijabat, 5th ed. (Jakarta: Erlangga, 2002), 79; Robert Henry Thouless, An Introduction to the Psychology of Religion (New York: Cambridge University Press, 1971), 87, https://books.google.co.id/books/about/An_Introduction_to_the_Psychology_of_Rel.html?id=aGg4AAA AIAAJ\&redir_esc=y.

${ }^{26}$ Hasyim Hasanah, "Peran Strategis Aktivis Perempuan Nurul Jannah al-Firdaus dalam Membentuk Kesadaran Beragama Perempuan Miskin Kota," Inferensi: Jurnal Penelitian Sosial Keagamaan 7, no. 2 (2013): 473-92, https://doi.org/10.18326/infsl3.v7i2.473-492. 
nanganan yang berbeda dengan anak pada umumnya. Problem pegetahuan yang berkaitan dengan bagaimana seorang mengerti dan memahami ajaran agamanya juga berkaitan dengan persoalan kebutuhan manusia. Keberagamaan bukan hanya sebagai kewajiban melainkan juga sebagai kebutuhan individu yang tidak dapat diabaikan. Hurlock mengatakan bahwa keyakinan terhadap Tuhan sangat menentukan kebahagiaan seseorang. ${ }^{27}$ Oleh karenanya, remaja harus membuat penilaian yang realistik terhadap kekuatan dan kelemahan diri terutama sebagai makhluk religi atau beragama. Ketaatan orang dalam menjalankan ajaran agamanya ditunjang dari ciri-ciri yang melekat pada individu yang memiliki keyakinan tinggi. Dasar pertimbangannya bahwa seseorang yang memiliki keagamaan yang tinggi selalu memandang positif kehidupan ini, sehingga berupaya semaksimal mungkin untuk mencapai apa yang diinginkannya, dengan mengembangkan potensi yang ada pada dirinya.

Problem ritual dan pengalaman ABH berkaitan dengan bagaimana seorang $\mathrm{ABH}$ memiliki kemampuan dalam menjaalankan ritualistik keagamaan, serta berperilaku lebih baik dalam kehidupannya. Ketidakmampuan ABH dalam menjalankan ritual keagamann dan menunjukkan perilaku yang berakhlak karimah banyak disebabkan oleh beberapa faktor baik bersifat internal maupun eksternal. Faktor eksternal diyakini menjadi faktor penentu dari problem ritual dan pengalaman religiusitas $\mathrm{ABH}$. Hal ini ditunjukkan dari berbagai pengaruh lingkungan ABHyang mendorongnya melakukan perilaku kejahatan dan kriminal, serta enggaan beribadah. Realitas tersebut sejalan dengan teori conditional operan yang dikembangkan oleh aliran psikologi sosial yang menyebutkan bahwa lingkungan sosial memberian pengaruh yang besar terhadap perilaku seseorang. Lingkungan kondusif, cenderung memengaruhi perilaku yang baik, sedangkan lingkungan yang kurang kondusif cenderung menjadikan seseorang mudah dan terbiasa untuk melanggar aturan yang ada.

Berbagai problem religiusitas $\mathrm{ABH}$ harus ditangani secara tepat, mengingat $\mathrm{ABH}$ memiliki problem yang kompleks, tidak hanya problem hukum tetapi juga sosial, ekonomi, politif, dan keagamaan. Maka dari itu dibutuhkan upaya coping spiritual. Dipilihnya coping spiritual didasarkan pertimbangan

${ }^{2}$ Hurlock, Psikologi Perkembangan, 235 
bahwa setiap individu harus memiliki usaha untuk menangani masalahnya dengan memperhatikan nilai-nilai keagamaan yang diyakininya. Sebagai makhluk beragama, $\mathrm{ABH}$ perlu diselamatkan menurut kaidah yang terdapat dalam ajaran agama, sebagai langkah dakwah yang dituntunkan Rasulullah. Mengacu pada teori di atas, maka coping spiritual yang dapat berikan kepada ABH dalam upaya menumbuhkan dan menangani problem religiusitas adalah dengan dua bentuk kegiatan yaitu pembiasaan dan keteadanan.

Pembiasaaan menjadi hal penting dalam kajian psikologi belajar anaak, kerana anak akan terbiasa untuk melakukan hal ternaiknya, dan mengarahkan perkembangan jiwanya secara lebih positif. Pembiasaan melibatkan kerja kognitif, afektif, dan psikomotorik, al ini tentu sejalan dengan konsep psikologi perkembangan anak, dan sesuai dengan kualifikasi pembentukan jiwa perkembangan keagamaan pada anak. Anak yang dibiasakan untuk berperilaku baik, saat dewasa akan memiliki usaha yang sangat kuat untuk menghindarkan diri dari perilaku yang berpotensi buruk atau jelek. Sebaliknya, anak yang tidak dilatih untuk membiasakan berperilaku baik, cenderung mudah terkena dampak kenakalan dan berpotensi rawan konflik. Pembiasaan merupakan coping spiritual dalam bentuk positive active. Pada tahap pembiasaan anak akan didorong untuk memiliki pengertian, pemahaman, meningkatkan kesadaran tentang pentinngnya berperilaku baik dan positif.

Maksudin menyebutkan bahwa pembiasaan merupakan proses pembentukan kebiasaan untuk memperbaiki kebiasaan yang ada. Tujuannya agar seseorang memiliki sikap, dan perilaku yang lebih positif dan tepat. ${ }^{28}$ Pembiasaan sikap dan perilakuk memuat implementasi nilai-nilai moral (akhlak) sebagai sarana belajar dan latihan mengahadapi dan memecahkan persoalan yang dihadapi. Pembiasaan menitikberatkan pada pengalaman yang dilakukan secara berualang-ulang. Pembiasaan yang dilakukan pada hakikatnya mengandung nilai kebaikan dan pengembangan kearah lebih positif. Pembiasaan dilakukan melalui kegiatan keagamaan, seperti membaca Qur'an, mengikuti pengajian pondok, mengaji kitab, jamaah shalat fardhu.

\footnotetext{
${ }^{28}$ Maksudin, "Pengembangan Diri dan Pembiasaan dalam Pembelajaran 'Bahasa,"' Al-Mahāra: Jurnal Pendidikan Bahasa Arab 1, no. 1 (2015): 19-42, https://doi.org/10.14421/almahara.2015.11-02.
} 
Coping spiritual lainnya dilakukan dengan keteladanan. Keteladanan di dalam dakwah merupakan wujud konsistensi pengamalan ajaran agama melalui figur pribadi yang dapat memainkan peran dalam membiasakan berperilaku baik dan berakhlak karimah. Keteladanan dilakukan dalam setiap dimensi kehidupan, seperti berkata baik, suka membantu dan menolong orang lain. Keteladanan seorang pembimbing dan pengasuh mencerminkan bahwa segala perilakunya, sikap dan perbuatannya, dapat diteladani.29 Keteladanan merupakan proses yang memengaruhi perilaku agar sasaran yang diberi contoh dapat meniru, selanjutnya melakukan perbuatan baik yang dicohtohkan kepadanya. Pembimbing agama dan pengasuh yang intensif memberikan keteladanan, berpengaruh pada aktivitas seseorang, terutama ABH yang menjadii santri di pondok pesantren Raden Sahid.

Berdasarkan implementasi dua model coping spiritual tersebut, $\mathrm{ABH}$ telah mengalami perubahan orientasi religious, yang awalnya memiliki problem keyakinan, pengetahuan, ritual dan pengalaman, inii berangsur memiliki pemahaman yang baik tentang ajaran Islam. Memeiliki kesediaan dan kerelaan dalam menjalankan perintah shalat, jamaah, dan pengajian. Memiliki penghayatan yangtinggi terhadap ajaran agamanya, terbukti yang awalnya suka mencuri, menjadi pribadi yang justru suka member dan menolong orang lain. ABH yang suka minnum-minuman keras, perilakunya berangsur menjadi lebih baik dan tidak melakukan minum-minuman keras. Dan justru kebanyakan santri tersebut aktif memakmurkan masjid an berpartsisipasi aktif dalam setiap program pondok pesantren Raden Sahid.

\section{E. Simpulan}

Problem religiusitas ABH meliputi problem keyakinan, ritual, penghayatan, pengetahuan, dan pengalaman keagamaan yang rendah. Problem keagamaan muncul karena $\mathrm{ABH}$ secara umum tidak memiliki latar belakang kehidupan yang baik. lingkungan sosial yang mereka miliki merupakan lingkungan sosial yang kurang baik. Usaha yang dilakukan oleh pondok pesantren Raden Sahid

${ }^{29}$ Nur Hidayat, "Implementasi Pendidikan Karakter Melalui Pembiasaan di Pondok Pesantren Pabelan,” Jurnal Pendidikan Sekolah Dasar 2, no. 1 (2015): 95-106, https://www.neliti.com/id/ publications/70998/implementasi-pendidikan-karakter-melalui-pembiasaan-di-pondok-pesantrenpabelan. 
dalam menangani persoalan religiusitas remaaja dengan menerapkan coping spiritual. Adapun bentuk coping spiritual tersebut adalah pembiasaan dan keteladanan. ABH yang awalnya memiliki keyakinan, ritual, penghayatan, pengetahuan, dan pengalaman keagamaan yang rendah, kini telah terbiasa untuk melaksanakan dan meningkatkan orientasi religiusitasnya, yang diperoleh dari figure pengasuh dan pembimbing agama.[s]

\section{Daftar Pustaka}

Andina, Elga. "Kejahatan Sadis oleh Remaja: Studi Kasus Begal Sepeda Motor di Kota Depok." Aspirasi: Jurnal Masalah-Masalah Sosial 6, no. 2 (2015): 145-58. http://jurnal.dpr.go.id/index.php/aspirasi/article/view/623.

Aviyah, Evi, dan Muhammad Farid. "Religiusitas, Kontrol Diri dan Kenakalan Remaja." Persona: Jurnal Psikologi Indonesia 3, no. 2 (2014): 126-29. https://doi.org/10.30996/persona.v3i02.376.

Billings, Andrew G., dan Rudolf H. Moos. "Coping, Stress, and Social Resources among Adults with Unipolar Depression." Journal of Personality and Social Psychology 46, no. 4 (1984): 877-91. https://doi.org/10.1037/ 0022-3514.46.4.877.

Daradjat, Zakiah. Ilmu Jiwa Agama. Jakarta: Bulan Bintang, 1979.

Gafoer, Abdul Rahmat, M. Syukri Akub, and Muhadar. "Anak Sebagai Pelaku Tindak Pidana Penganiayaan." Fakultas Hukum Program Pascasarjana (S2) Universitas Hasanuddin Makassar, n.d.

Hasanah, Hasyim. "Peran Strategis Aktivis Perempuan Nurul Jannah al-Firdaus dalam Membentuk Kesadaran Beragama Perempuan Miskin Kota." Inferensi: Jurnal Penelitian Sosial Keagamaan 7, no. 2 (2013): 473-92. https://doi.org/10.18326/infsl3.v7i2.473-492.

Hidayat, Nur. "Implementasi Pendidikan Karakter Melalui Pembiasaan di Pondok Pesantren Pabelan." Jurnal Pendidikan Sekolah Dasar 2, no. 1 (2015): 95-106. https://www.neliti.com/id/publications/70998/ implementasi-pendidikan-karakter-melalui-pembiasaan-di-pondokpesantren-pabelan. 
Hikmah, Siti. Psikologi Perkembangan: Tinjauan dalam Persepektif Islam. Semarang: Karya Abdi Jaya, 2015.

Hurlock, Elizabeth B. Perkembangan Anak. Jakarta: Erlangga, 2013.

-_- Psikologi Perkembangan: Suatu Pendekatan Sepanjang Rentang Kehidupan. terj. Ridwan Max Sijabat. 5th ed. Jakarta: Erlangga, 2002.

Lazarus, R. S. "Coping Theory and Research: Past, Present, and Future." Psychosomatic Medicine 55, no. 3 (1993): 234-47. https://doi.org/ 10.1097/00006842-199305000-00002.

Maksudin. "Pengembangan Diri dan Pembiasaan dalam Pembelajaran 'Bahasa."' Al-Mahāra: Jurnal Pendidikan Bahasa Arab 1, no. 1 (2015): 19-42. https://doi.org/10.14421/almahara.2015.11-02.

Purnama, Rahmad. "Penyelesaian Stress Melalui Coping Spiritual." Al-Adyan 12, no. 1 (2017): 70-83. https://doi.org/10.24042/ADYAN.V12I1.1445.

Putra, Redian Syah, dan Yoskar Kadarisman. "Kriminalitas di Kalangan Remaja (Studi terhadap Remaja Pelaku Pencabulan di Lembaga Pemasyarakatan Anak Kelas II B Pekanbaru)." Jurnal Online Mahasiswa (JOM) Bidang Ilmu Sosial dan Ilmu Politik 3, no. 1 (2016): 1-14. https://jom.unri. ac.id/index.php/JOMFSIP/article/view/9336.

Rahmawati, Diah Viska, M Noor Rochman Hadjam, dan Tina Afiatin. "Hubungan Antara Kecenderungan Perilaku Mengakses Situs Porno dan Religiusitas pada Remaja." Jurnal Psikologi 29, no. 1 (2002): 1-13. https:// doi.org/10.22146/JPSI.7044.

Shia, Regina M. "Assessing Academic Intrinsic Motivation: A Look at Student Goals and Personal Strategy." Wheeling Jesuit University, n.d. http://www.cet.edu/pdf/motivation.pdf.

Sholikhati, Yunisa, dan Ike Herdiana. "Anak Berkonflik dengan Hukum (ABH), Tanggung Jawab Orang Tua Atau Negara?" In Seminar Psikologi dan Kemanusiaan. Malang: Psychology Forum UMM, 2015. http:// mpsi.umm.ac.id/files/file/464-469 Yunisa S.pdf.

Sudarsono. Etika Islam tentang Kenakalan Remaja. Jakarta: Rineka Cipta, 2008.

Suidah, Hartin. "Hubungan Pemahaman Tingkat Agama (Religiusitas) dengan Perilaku Seks Bebas pada Remaja di SMAN 1 Bangsal Mojokerto." Jurnal Keperawatan \& Kebidanan 7, no. 2 (2015): 63-68. 
Sururin. Ilmu Jiwa Agama. Jakarta: Raja Grafindo Persada, 2004.

Thouless, Robert Henry. An Introduction to the Psychology of Religion. New York: Cambridge University Press, 1971. https://books.google.co.id/ books/about/An_Introduction_to_the_Psychology_of_Rel.html?id=aGg4 AAAAIAAJ\&redir_esc=y.

Wigfield, Allan, dan Jacquelynne S. Eccles. "Expectancy-Value Theory of Achievement Motivation." Contemporary Educational Psychology 25, no. 1 (2000): 68-81. https://doi.org/10.1006/ CEPS.1999.1015.

Wiyono, R. Sistem Peradilan Pidana Anak di Indonesia. Jakarta: Sinar Grafika, 2016. 
This page intentionally left blank 